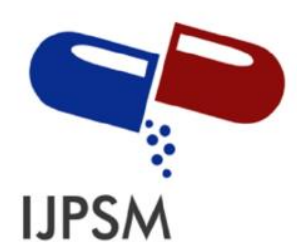

Thasa Muthia Wulandari et al, Int. Journal of Pharmaceutical Sciences and Medicine (IJPSM),

Vol.6 Issue. 6, June- 2021, pg. 34-41

\title{
An Overview of the Traditional Uses, Phytochemicals, and Pharmacological Activities of Tempuyung (Sonchus arvensis L.)
}

\author{
Thasa Muthia Wulandari $^{1}$; Boy Chandra ${ }^{1}$; Zulharmita ${ }^{1}$; Harrizul Rivai ${ }^{2 *}$ \\ ${ }^{1}$ College of Pharmacy (STIFARM), Jl. Raya Siteba Kurao Pagang, Padang 25147, Indonesia \\ ${ }^{2}$ Faculty of Pharmacy, Andalas University, Limau Manih Campus, Padang 25163, Indonesia \\ *Email: harrizul@yahoo.co.id and harrizul@phar.unand.ac.id \\ DOI: 10.47760/ijpsm.2021.v06i06.004
}

\begin{abstract}
Tempuyung (Sonchus arvensis L.) is one of the herbs that the community has widely known. This plant is easy to come by and has excellent benefits. Therefore, it is necessary to obtain information about phytochemicals and their pharmacological effects. Information search is done by literature studies in primary data or official book forms and international journals through trusted websites such as Mendeley, Scopus, ScienceDirect, NCBI, ResearchGate, Google Scholar, Pubmed. The results showed tempuyung has phytochemical compounds, especially flavonoids and derivatives such as kaempferol, rutin, and quercetin. This compound is isolated from the leaves of tempuyung by various extraction methods. Pharmacologically, this plant has been reported to have antibacterial and antiviral, diuretic, kidney stones, antihistamine, antihypertensive, and antihyperuricemia. Thus, tempuyung can be used as an ingredient for traditional medicine, and further research needs to be done to isolate medicinal compounds from tempuyung.
\end{abstract}

Keywords: Tempuyung, Sonchus arvensis L., Traditional Uses, Phytochemistry, Pharmacological Activities

\section{Introduction}

Tempuyung plant (Sonchus arvensis L.) is an herb, which grows wild and easy to find in the yard, field, roadside, between trenches, or unkempt walls. Tempuyung (Sonchus arvensis L.) plant has been used since old times as traditional medicine, commonly used to overcome disorders related to kidney organs due to the decay of kidney stones and diuretics [1].

Tempuyung (Sonchus arvensis L.) belongs to the family Asteraceae, which grows at an altitude of 50-1,600 meters above sea level and is usually found in environments with even rainfall throughout the year cool weather or areas with short dry seasons. As a wild plant, tempuyung (Sonchus arvensis L.) can also be cultivated in the yard. This plant belongs to the plant without woody and likes a place exposed to direct sunlight and easy to breed with seeds carried by the wind [2]. Tempuyung plants look like in Figure 1, and germs that can be blown away by the wind can be seen in Figure 2 below. 


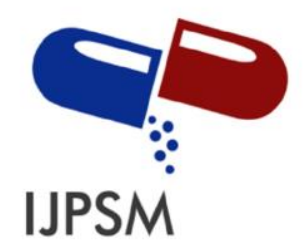

Thasa Muthia Wulandari et al, Int. Journal of Pharmaceutical Sciences and Medicine (IJPSM), Vol.6 Issue. 6, June- 2021, pg. 34-41

ISSN: 2519-9889

Impact Factor: 3.426

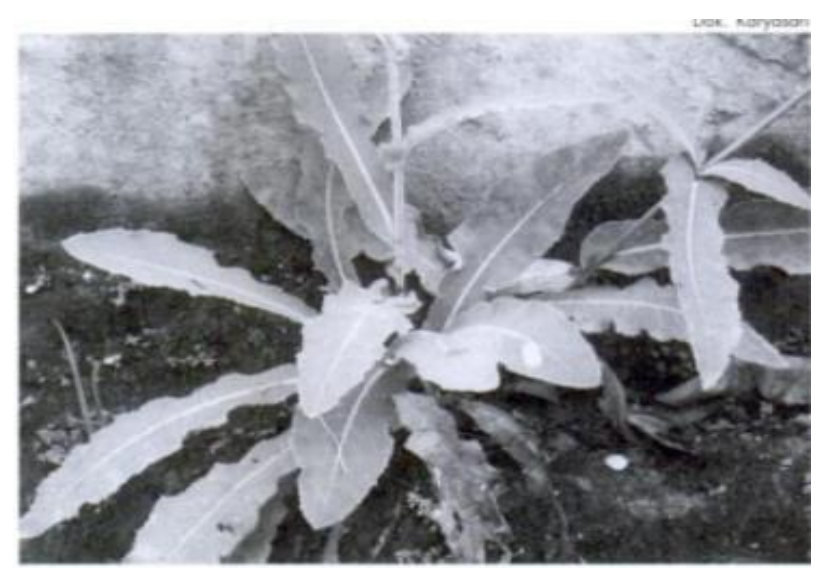

Figure 1: Tempuyung Plants [1]

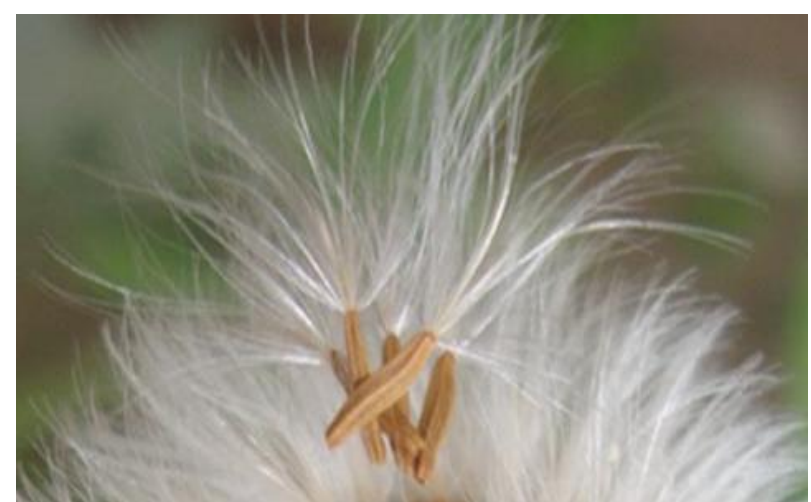

Figure 2: Fruit or seeds ready to be flown by the wind [1]

\section{Scientific classification [1]:}

Kingdom: Plantae

Division: Magnoliophyta

Ordo: Monocotyledon

Class: Angiospermae

Family: Asteraceae

Species: Sonchus arvensis L.

Tempuyung plant (Sonchus arvensis L.) contains chemical compounds, like flavonoids which are productive as antibacterial and antivirus, diuretic, kidney stones, antihistamine, antihypertensive, and antihyperuricemia. The effect of tempuyung leaves (Sonchus arvensis L.) is caused by alkaloid compounds, flavonoids, phenols, saponins, and tannins [3].

\section{Data collection}

In compiling this article, the technique used is to use literature studies by searching for sources or literature in primary data or the shape of official books and journals International within the last 20 years (2000-2020). Therefore, the creation of this review article looks for data using online media with the keyword is Tempuyung, Sonchus arvensis. L, Traditional Uses. The primary references are through trusted websites such as Mendeley, Scopus, ScienceDirect, NCBI, ResearchGate, Google Scholar, Pubmed, and other journals published. 


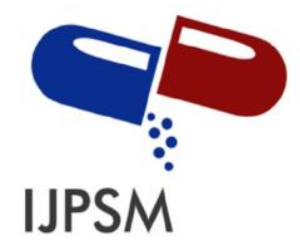

Thasa Muthia Wulandari et al, Int. Journal of Pharmaceutical Sciences and Medicine (IJPSM), Vol.6 Issue. 6, June- 2021, pg. 34-41

ISSN: 2519-9889

Impact Factor: 3.426

\section{Traditional uses of tempuyung}

Traditional medicine is an ingredient or herb in plants, animal parts, minerals, or a mixture of these ingredients used for generations for treatment. Based on genetic evidence and experience (empirical), traditional medicine is still used by the people of Indonesia. As a cultural heritage of the nation that has been proven to contribute a lot to health maintenance. Jammu is a traditional medicine native to Indonesia needs to be preserved and developed [4].

In history, driven and supported by the development of science and technology and the needs of modern health efforts, traditional medicine has undergone many expansions. The products in question include aspects of proving efficacy and safety, quality, dosage form, way of delivery, packaging, and production technology. To encourage the increasing utilization of traditional Indonesian medicine while ensuring the preservation of herbal medicine, Indonesia programs the development in stages into groups of herbal treatments, standardized herbal drugs, and phytopharmaceuticals [4]. Traditionally tempuyung plants (Sonchus arvensis L.) are medicinal, especially decaying or destroying kidney stones [3]. It has been trusted and used by Indonesian people for generations.

\section{Flavonoid compounds in tempuyung}

Based on the literature review, tempuyung contains phytochemical compounds, especially flavonoids and their derivatives such as kaempferol, rutin, and quercetin. Flavonoid compounds are secondary metabolites produced by plants. Flavonoid is one of the most significant natural class compounds in plants and is arranged by 15 carbon atoms as the essential core. This compound set from configuration C6-C3-C6 is two aromatic rings connected by three carbon rings [5]. Flavonoids are found in all green plants to be found in every plant extract [6]. The structure of flavonoid compounds shown in Figure 3 and the construction of kaempferol, rutin, and quercetin are shown in Figures 4, 5, and 6.

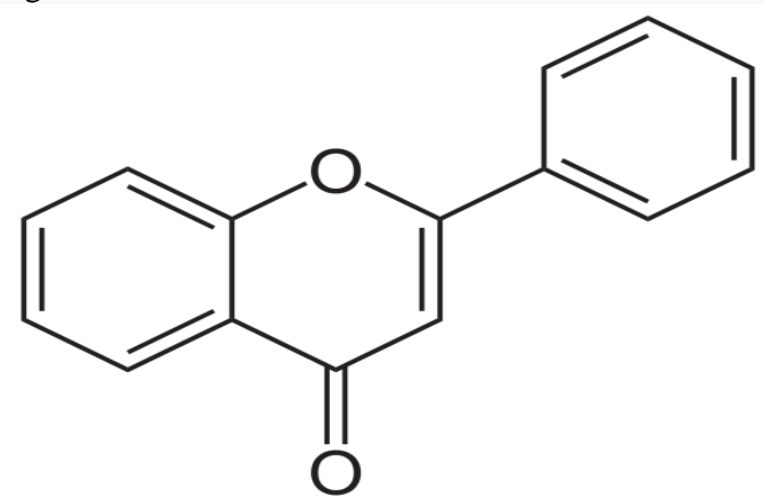

Figure 3: Structure of flavonoid compounds [5]

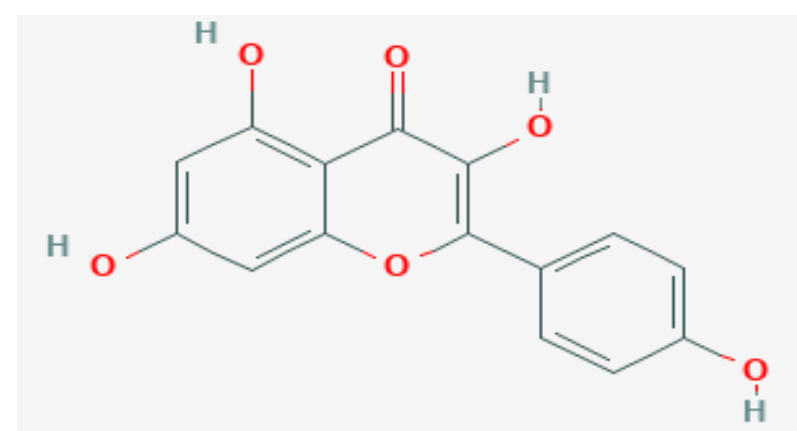

Figure 4: Kampferol structure [7] 


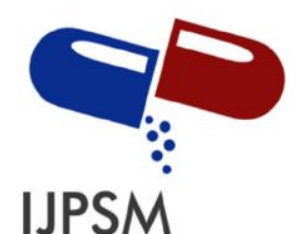

Thasa Muthia Wulandari et al, Int. Journal of Pharmaceutical Sciences and Medicine (IJPSM),

Vol.6 Issue. 6, June- 2021, pg. 34-41

ISSN: 2519-9889

Impact Factor: 3.426

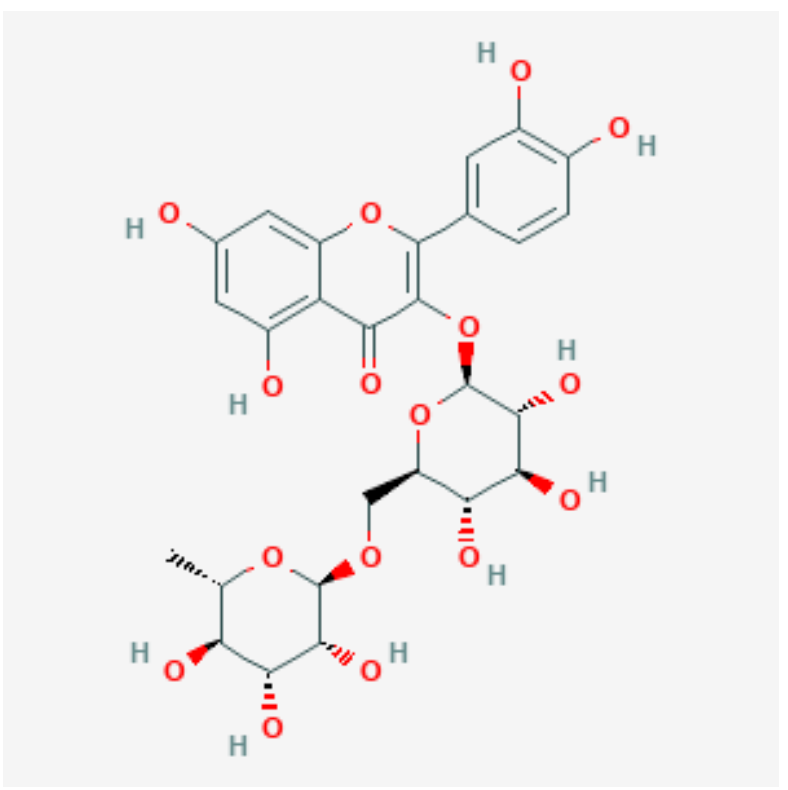

Figure 5: Rutin structure [7]<smiles>O=c1c(O)c(-c2ccc(O)c(O)c2)oc2cc(O)cc(O)c12</smiles>

Figure 6: Quercetin structure [7]

Many studies have shown that flavonoid derivatives such as rutin, kaempferol, quercetin, apigenin are well-known for anti-inflammatory, antiallergic, antithrombotic, hepatoprotective, antispasmodic, and anticancer properties [8].

Extract of tempuyung leaves is an extract made from the leaves of Sonchus arvensis L., family Asteraceae, containing flavonoid total about $0.1044 \%$, potentially an antioxidant [1]. Each part of plant morphology has different antioxidant activity due to the variation in phenolic content and flavonol.

Compounds that act as antioxidants are flavonoid compounds with their main components type quercetin. Antioxidants are compounds that can inhibit reactive oxygen (ROS) and free radicals in the body [9]. When antioxidants are bound to excess ROS, cells damaged by ROS have a generational time. In such events can be seen that ethanol extract tempting leaves (Sonchus arvensis L.) can affect the regeneration of damaged cells in tubular cells due to free radicals [3]. 


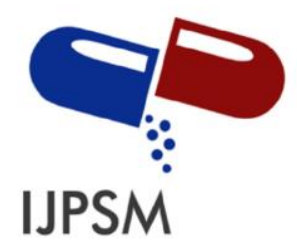

Thasa Muthia Wulandari et al, Int. Journal of Pharmaceutical Sciences and Medicine (IJPSM), Vol.6 Issue. 6, June- 2021, pg. 34-41

ISSN: 2519-9889

Impact Factor: 3.426

\section{Pharmacological activities of tempuyung 5.1 Antibacterial and Antivirus}

Research shows pedestal plants (Sonchus arvensis L.) have antibacterial properties [10]. Furthermore, it is known that the immunomodulatory activity of ethanol extract of tempuyung leaves (Sonchus arvensis L.) has flavonoid compounds. It has been examined in male rat strain Wistar at a dose of $100 \mathrm{mg} / \mathrm{kg} \mathrm{BW}, 700 \mathrm{mg} / \mathrm{kg}$ BW, and $1400 \mathrm{mg} / \mathrm{kg} \mathrm{BW}$. An immunomodulator is a substance that can modulate or affect the body's immune system in an average direction. With a sound immune system, the body can avoid various bacterial and virus infections. Therefore, tempuyung plants (Sonchus arvensis L.) can also be said to be antivirus. One of the diseases caused by bacterial infection is basilar dysentery, caused by bacteria $S$. dysenteriae [11].

In the results of Susilo's 2013 study, there is flavonoid content that is kaempferol in tempuyung leaves (Sonchus arvensis Linn.) that works against lymphokine (Interferon $\gamma$ ) produced by T cells so that it will stimulate phagocyte cells to respond to phagocytosis. As a result, it can spur the proliferation of lymphocytes, increase the number of T cells, and increase the production of IL-2 [12]. Swarnalatha's 2014 research also said that kaempferol could increase phagocytes and can increase IL-2 significantly. IL-2 is one of the cytokines that regulate the immune response and serves as a mitogen for $\mathrm{T}$ cells. Therefore, it can potentially improve the proliferation and function of T cells, B cells, and NK cells, enhance the formation of antigens, and increase the production and release of other cytokines [13].

\subsection{Diuretics}

Diuretics are medicine used to remove excess salt and water from the body through urine. Tempuyung plant (Sonchus arvensis L.), used as a diuretic, is commonly used to overcome disorders related to kidney organs because it decays kidney stones [1]. The diuretic effect obtained comes from ethanol extract of tempuyung leaves with the active antioxidant content of flavonoids. Research shows the effect of protection of ethanol extract tempuyung against kidney injury [14].

In addition, tempuyung leaves can be used as a diuretic drug because they have a high potassium chemical compound content. The high potassium content is what makes kidney stones in the form of calcium carbonate scattered. Potassium will get rid of calcium to join oxalate, carbonate, or vein compounds that are the shapers of kidney stones. The kidney stone deposits eventually come out and dissolve with urine [1].

\subsection{Kidney stone}

Kidney stones (nephrolithiasis) are formed due to the accumulation of calcium crystals of calcium crystallization in the urinary tract and usually cause pain, blockage of urine, and kidney damage [15]. In addition, calcium crystals that settle in the kidneys can trigger inflammation of the epithelium that causes cell death (necrosis) that will affect the immune system.

Infectious agents that enter the body will be responded to by innate immunity, which is then answered by the adaptive immune. The adaptive immune response is a defense mechanism of the body in resistance to specific antigens. For example, Tempuyung (Sonchus arvensis L.) is a medicinal plant used to destroy kidney stones [16]. Therefore, the content of flavonoid compounds in leaf extract tempuyung (Sonchus arvensis L.) can be used to stimulate adaptive immune response [15].

\subsection{Antihistamine}

Antihistamine is a substance that can reduce or block the effect of histamine on the body by blocking histamine receptors [17]. When histamine fights, the body will experience inflammation. But in people with allergies, the performance of histamine becomes chaotic because these chemicals can no longer distinguish objects that are harmful and that are not harmful to the body, such as dust, animal fur, or food. As a result, it causes the body to continue to experience inflammation or allergic reactions when harmless objects enter the body.

The compound flavonoid in tempuyung leaf extract (Sonchus arvensis L.) can be used as an antihistamine. Tempuyung leaf extract (Sonchus arvensis L.) may increase immunomodulatory activity [10]. Where it significantly lowers the profile of cell B. In addition, suppression of cell B may trigger homeostatic movement 


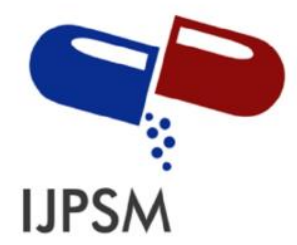

Thasa Muthia Wulandari et al, Int. Journal of Pharmaceutical Sciences and Medicine (IJPSM), Vol.6 Issue. 6, June- 2021, pg. 34-41

ISSN: 2519-9889

Impact Factor: 3.426

[15]. Homeostasis is an automatic process and mechanism performed by living beings to maintain a stable condition so that their body can function normally, despite changes in the environment inside and outside the body, so that an immune response occurs. The resulting immune response is an IgE antibody secreted to fight allergies.

\subsection{Antihypertensive}

Ethanol extract of tempuyung leaves (Sonchus arvensis L.) can be used in inhibiting the activity of Angiotensin-Converting Enzyme (ACE). Angiotensin is a hormone that plays a vital role in regulating blood pressure. Angiotensin levels that are too high or too low can trigger various problems such as high blood pressure. Angiotensin has a precursor that is angiotensinogen secreted by the liver, which will turn into Angiotensin I, then Angiotensin-Converting Enzyme (ACE) will turn it into Angiotensin II. Angiotensin II plays a role in hypertension because it has a strong vasoconstriction effect in inducing hypertension. Sonchus arvensis L. ethanol extract made by maceration method with ethanol solvent $96 \%$. ACE bland extract activity is evaluated using the N-hippuric-L-histidyl-L-leucine (HHL) substrate and will be split by ACE. The inhibitory activity of tempuyung leaf ethanol extract (Sonchus arvensis L.) against ACE is calculated based on the amount of hippuric acid formed and calculated based on absorbant values at wavelengths of $228 \mathrm{~nm}$ measured using UV spectrophotometers [18].

The ethanol extract of tempuyung leaves (Sonchus arvensis L.) has ACE inhibition activity on $\mathrm{IC}_{50}$ of 46.71 $\mu \mathrm{g} / \mathrm{mL}$ and $\mathrm{IC}_{50}$ of captopril as a drug reference of $1.26 \mu \mathrm{g} / \mathrm{mL}$. Thus it can be said that the inhibitory activity of ethanol extract is lower than captopril. So it can be said that tempuyung (Sonchus arvensis L.) is potentially used as an ACE inhibitor and potentially to be developed as an antihypertensive [18].

Ethanol extract of tempuyung leaves (Sonchus arvensis L.) is potentially an ACE inhibitor that acts as an antihypertensive. It is due to flavonoid compounds such as kaempferol, quercetin, orientin, hyperoxide, catechin, rutin, and myricetin in ethanol extract of tempuyung leaves (Sonchus arvensis L.) [19] One flavonoid that acts as an ACE inhibitor is kaempferol and quercetin.

\subsection{Antihyperuricemia}

Uric acid is a heterocyclic substance derived from the metabolic breakdown of purine compounds in the body. A condition where there are high levels of uric acid $(>7 \mathrm{mg} / \mathrm{dL})$ in the human body is called hyperuricemia [20]. Treatment can be done, but if consumed continuously, it can cause side effects. Therefore alternative drugs are needed with minimal side effects and are easy to obtain, such as tempuyung plants (Sonchus arvensis L.) [21]. Tempuyung (Sonchus arvensis L.) is a traditional herb often used as a drug for hyperuricemia. Tempuyung leaf extract (Sonchus arvensis L.) contains active flavonoid compounds of the quercetin group that inhibit the enzyme xanthine oxidase. As a result, it can ward off free radicals, making it potentially an antihyperuricemia [22].

\section{Conclusion}

The review stated that tempuyung (Sonchus arvensis L.) contains flavonoid compounds and their derivatives, such as kaempferol, rutin, and quercetin. Pharmacologically, this plant has been reported to have antibacterial and antiviral, diuretic, kidney stones, antihistamine, antihypertensive, and antihyperuricemia. Thus, tempuyung can be used as an ingredient for traditional medicine, and further research needs to be done to isolate medicinal compounds from tempuyung.

\section{References}

[1]. Winarto IW, Karyasari T. Tempuyung; Tanaman Penghancur Batu Ginjal. AgroMedia; 2004.

[2]. Harahap NI. Skrining dan karakterisasi simplisia daun tempuyung (Sonchus arvensis. L). JIFI (Jurnal Ilmiah Farmasi Imelda). 2019 Dec 18;3(2):45-51.

http://jurnal.uimedan.ac.id/index.php/JURNALFARMASI/article/view/212 


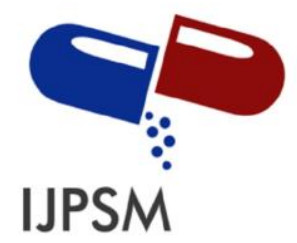

Thasa Muthia Wulandari et al, Int. Journal of Pharmaceutical Sciences and Medicine (IJPSM), Vol.6 Issue. 6, June- 2021, pg. 34-41

ISSN: 2519-9889

Impact Factor: 3.426

[3]. Tandi J, Sutrisna IN, Pratiwi M, Handayani TW. Potential Test of Nephropathy Sonchus arvensis L. Leaves on Male Rats (Rattus norvegicus) Diabetes Mellitus. Pharmacognosy Journal. 2020; 12(5). https://www.phcogj.com/article/1218.

[4]. RI, Departemen Kesehatan. Farmakope Herbal Edisi II. Jakarta:Departemen Kesehatan RI;2017.p.vii

[5]. Wang TY, Li Q, Bi KS. Bioactive flavonoids in medicinal plants: Structure, activity, and biological fate. Asian Journal of Pharmaceutical Sciences. 2018 Jan 1;13(1):12-23. https://www.sciencedirect.com/science/article/pii/S1818087617301940

[6]. Arifin B, Ibrahim S. Struktur, bioaktivitas dan antioksidan flavonoid. Jurnal Zarah. 2018 Apr 1;6(1):21-9.. http://ojs.umrah.ac.id/index.php/zarah/article/view/313.

[7]. https://pubchem.ncbi.nlm.nih.gov

[8]. Kumar S, Pandey AK. Chemistry and biological activities of flavonoids: an overview. The scientific world journal. 2013 Oct; 2013. https://www.hindawi.com/journals/tswj/2013/162750/abs/.

[9]. Chairul SM, Sumarny R. Antioxidant activity of aqueous extract of Sonchus arvensis L. in-vitro. Indonesian Journal of Pharmacy. 2005 Oct 1:208-15.. http://indonesianjpharm.farmasi.ugm.ac.id/index.php/3/article/view/769

[10]. Kanaan S, Sani AM, Yaghooti F. Antibacterial effects and chemical composition of essential oils from Cotoneaster nummularioides pojark and Sonchus arvensis L. leaves extracts on typical food-borne pathogens. International Journal of Biosciences (IJB). 2015;6(2):357-65. -365. https://www.cabdirect.org/cabdirect/abstract/20153150956

[11]. Sukmayadi AE, Sumuwi SA, Aryanti AD. Aktivitas Imunomodulator Ekstrak Etanol Daun Tempuyung (Sonchus arvensis Linn.). Indonesian Journal of Pharmaceutical Science and Technology. 2014 Oct 1;1(2):42.. http://jurnal.unpad.ac.id/ijpst/article/view/7515.

[12]. Susilo J, Erwiyani AR, Pratiwi TD. The immunomodulatory effect of ethyl acetate fraction of Sonchus arvensis L. leaves toward nonspecific immune response on male mice Balb/c strain.

[13]. Swarnalatha S, Puratchikody A. Cytokine Mediated Immunomodulatory Properties of kaempferol-5-O- $\beta$-Dglucopyranoside from methanol extract of aerial parts Indigofera aspala-thoides Vahl ex DC.. https://www.researchgate.net/profile/Ayarivan_Puratchikody/publication/282819672_Cytokine_mediated_immuno modulatory_properties_of_Kaempferol-5-O-b-D-

glucopyranoside_from_methanol_extract_of_aerial_parts_of_Indigofera_aspalathoides_Vahl_ex_DC/links/564457 e008aef646e6ca7b81/Cytokine-mediated-immunomodulatory-properties-of-Kaempferol-5-O-b-D-glucopyranosidefrom-methanol-extract-of-aerial-parts-of-Indigofera-aspalathoides-Vahl-ex-DC.pdf.

[14]. Imelda I, Azaria C, Lucretia T. Protective Effect of Ethanol Extract Tempuyung Leaf (Sonchus arvensis L.) Against Gentamicin Induced Renal Injury Viewed from Blood Ureum Level. Journal of Medicine and Health. 2017 Aug 31;1(6).. https://journal.maranatha.edu/index.php/jmh/article/view/555

[15]. Maghfiroh K, Rifa'i M, Widyarti S. Adaptive Immune Response Stimulation on Nephrolithiasis Mice Model after Treatment of Tempuyung (Sonchus arvensis L.) Leaf Extract. The Journal of Experimental Life Science. 2014;4(2):34-8.. https://www.jels.ub.ac.id/index.php/jels/article/view/147.

[16]. Hidayati A, Anggraini YH. Pengaruh Frekuensi Penggunaan Teh Daun Tempuyung Kering (Sonchus Arvensis) Terhadap Daya Larut Kalsium Oksalat. Jurnal Kesehatan. 2009;2(2). https://jurnal.unimus.ac.id/index.php/Analis/article/view/300.

[17]. Sari F, Yenny SW. Antihistamin terbaru dibidang dermatologi. Jurnal Kesehatan Andalas. 2018 Dec 31;7:61-5. http://jurnal.fk.unand.ac.id/index.php/jka/article/view/924

[18]. Sukandar EY, Sutjiatmo AB, vikasari SN. Angiotensin-converting enzyme inhibitor activity of ethanol extract of Sonchus arvensis (Linn.) leaves. InProceedings of the 6th International Conference on Bioinformatics and Biomedical Science 2017 Jun 22 (pp. 124-128).https://doi.org/10.1145/3121138.3121195

[19]. Khan RA. Evaluation of flavonoids and diverse antioxidant activities of Sonchus arvensis. Chemistry Central Journal. 2012 Dec;6(1):1-7.https://bmcchem.biomedcentral.com/articles/10.1186/1752-153X-6-126

[20]. Waly TA, Brajawikalpa RS, Nurbaiti N. Comparison of Uric Acid Level Reduction by Administration of Tempuyung (Sonchus arvensis) Leaf Extract and Breadfruit (Artocarpus altilis) Leaf Extract in Hyperuricemic Wistar Rats. International Conference on Agriculture, Social Sciences, Education, Technology and Health (ICASSETH 2019) 2020 Apr 7 (pp. 205-207). Atlantis Press. https://download.atlantis-press.com/proceedings/icasseth-19/125938594

[21]. Brajawikalpa RS, Basyir PB, Nirmala N. Uji Efektifitas Ekstrak Daun Tempuyung (Sonchus arvensis L.) untuk Menurunkan Kadar Asam Urat pada Tikus Putih Wistar Jantan yang Dibuat Hiperurisemia. Tunas Medika Jurnal Kedokteran \& Kesehatan. 2018 Jun 15;4(2).. 


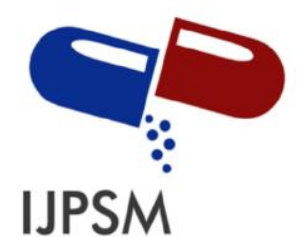

Thasa Muthia Wulandari et al, Int. Journal of Pharmaceutical Sciences and Medicine (IJPSM), Vol.6 Issue. 6, June- 2021, pg. 34-41

ISSN: 2519-9889

Impact Factor: 3.426

[22]. Hendriani R, Nursamsiar, Tjitraresmi A. In Vitro And In Silico Evaluation of Xanthine Oxidase Inhibitory Activity of Quercetin Contained In Sonchus Arvensis Leaf Extract. Asian Journal of Pharmaceutical and Clinical Research. Special Issue May 2017

https://www.researchgate.net/profile/Rini_Hendriani/publication/317649517_In_vitro_and_in_silico_evaluation_of _xanthine_oxidase_inhibitory_activity_of_quercetin_contained_in_sonchus_arvensis_leaf_extract/links/5aa9efae45 $851517881988 \mathrm{dd} /$ In-vitro-and-in-silico-evaluation-of-xanthine-oxidase-inhibitory-activity-of-quercetin-containedin-sonchus-arvensis-leaf-extract.pdf.

\section{A Brief Author Biography}

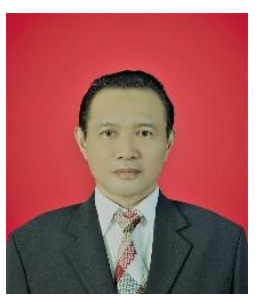

Prof. Dr. Harrizul Rivai, M.S. was born in Payakumbuh, West Sumatra, on 4 September 1953. His father is Rivai Said, and his mother is Saridahanum Syofyan. The Author obtained a Bachelor of Pharmacy from the Department of Pharmacy, Faculty of Mathematics and Natural Sciences, Padjajaran University, Bandung (1976), a Master of Science degree from the Bandung Institute of Technology (1984), and a Doctorate from the Department of Chemistry, Faculty of Mathematics and Natural Sciences, Andalas University, Padang (2011). Now the Author is a Professor and Researcher at the Faculty of Pharmacy, Andalas University, Padang. The Author also serves as Deputy Chair of Academic Affairs at the YPTIK Padang College of Pharmacy (STIFARM). The Author wrote the book "Principles of Chemical Examination" (Publisher UI-Press, 1995), translated the book "Pharmaceutical Statistics" (EGC Medical Book Publishers, 2010), and wrote "Chapter 4 " in the book "Recent Research Advances in Biology Vol. 4" (Book Publisher International, India, and United Kingdom, 2020), and wrote the book "Chinese Petai (Leucaena leucocephala): Traditional Uses, Phytochemicals, and Pharmacological Activities" (Deepublish, Yogyakarta, 2021). He wrote "Chapter 9" in the book "Recent Research Advances in Biology Vol. 7" and "Chapters 5, 6, 7, and 8" in the book "Technological Innovation in Pharmaceutical Research Vol. 3 (Book Publisher International, India, and United Kingdom, 2021). The Author has also written articles in various international journals in various science fields, such as chemistry, biology, and pharmacy. 